\title{
Defoliation Impacts on Quality and Quan- tity of Forage Harvested from Big Sacaton (Sporobolus wrightii Munro)
}

\author{
MARSHALL R. HAFERKAMP
}

\section{Abstract}

Forage quality and quantity and stand vigor of big sacaton were evaluated for seven defollation systems during 1977 and 1978. Big sacaton plants were either shredded monthly, shredded in spring /midsummer, spring/early summer, spring, spring/late summer / fall, midsummer/fall, or late winter. Forage quality of big sacaton was improved by defoliation during both years. With few exceptions, crude protein content was highest in plants defoliated the previous month. IVDOM contents were also improved by defoliation. Digestibility decreased to below $50 \%$ in early summer in nonshredded plants and in mid summer in all plants regardless of prior defoliation treatment. IVDOM increased to above $50 \%$ in late summer and fall in plots defoliated the previous month. Forage harvests during the growing season were greatest from plots that were defoliated three or more times and were defoliated in the fall. The least amounts of forage were harvested from the plots defoliated in spring, spring/early summer and spring/midsummer. In the fall and winter the nonshredded and spring defoliated plots supported relatively large amounts of forage, and the spring/early summer and spring/midsummer plots supported intermediate amounts of forage for winter grazing. Stand vigor was maintained best by brief periods of defoliation in the spring or spring/early summer, followed by defoliation of old forage in late winter. Vigor appeared to be decreased by early fall defoliations to $7.5 \mathrm{~cm}$ stubble height. The spring/early-summer system provided large amounts of high quality forage and maintained stand vigor. This system defoliated plants when soil moisture was usually adequate for plant regrowth, provided nutritious forage during the growing season and provided adequate standing forage for fall and winter grazing and protection against damage due to low temperature.

Big sacaton (Sporobolus wrightii Munro) is a robust perennial bunchgrass which occurs from Arizona to western Texas and south into Mexico (USFS 1937). The species grows mainly on low alluvial flats, bottomlands, and arroyos subject to flooding. Big sacaton will not generally grow on soils highly impregnated with alkali (Wooton and Standley 1912). Although it is a warm-season species, it begins growth early in the spring and may remain green throughout mild winters.

\footnotetext{
The author, formerly an assistant professor, Texas Agricultural Experiment Station. (Department of Range Science), Texas A\&M University, College Station 77843. Currently is an assistant professor, Eastern Oregon Agr. Res. Center, Squaw Butte, Oregon State University. Box 833, Burns, OR. 97720.

This report is approved for publication by the director, Texas Agricultural Experiment Station, as Tech. Article 15848.

The author greatly acknowledges the J.S. Abercrombie Foundation, Houston, Texas, for funding the project; Mr. George T. Jambers, Jr., for providing land and assistance for the study; and the U.S. Dep. Agr. Soil Conservation Service for cooperation in establishing the planting. The planting was established by Mr. George Jambers, Jr., in cooperation with Mr. Joe Coughran, district conservationist with the U.S. Dep. Agr. Soil Conservation Service stationed at Tilden. Texas. Plant materials were provided by the Soil Conservation Service Plant Materials Center, Knox City, Texas. The author is grateful to Mr. David Davidson, Mr. Gary Bowers, Dr. James George, and Mr. Keven Van Hook for help with plot installation, maintenance, and evaluation of the study. I also thank Mr. Ray Hinnant, Mrs. Julie Averit, and Ms. Mary Lee Skwirz for their assistance in analyzing samples, and Mr. Don Shelton for assistance in the statistical analysis.

Manuscript received March 4, 1980.
}

Early spring growth is readily grazed by animals and big sacaton has been mowed during the growing season for hay (Humphrey 1960). Griffiths et al. (1915) reported big sacaton contained $9.25 \%$ crude protein when harvested at flowering to a stubble height of 10 $\mathrm{cm}$. The plants produce a large volume of herbage which cures well and reportedly provide a source of good winter forage despite their coarseness (USFS 1937). However, Humphrey (1960) reported the mature foliage was rarely grazed. Rangemen have long been aware that grazing, mowing, or burning can affect yield and quality of forage (Youngner 1972). The USFS (1937) reported the abundance of big sacaton had been reduced in many areas by overgrazing, but careful management would apparently allow full use of the species and maintain stands in a productive state. Sacaton flats can be used most effectively by grazing heavily early in the spring and then deferring until fall (Humphrey 1960). The Soil Conservation Service (1979) suggests grazing of big sacaton plants no closer than 20 to $25 \mathrm{~cm}$ stubble heights and then resting for 4 to 6 months. Coarse, unpalatable mature growth may be removed by burning every 3 or 4 years with less damage occurring to big sacaton plants burned in late winter or early spring before growth begins (Humphrey 1960). Bock and Bock (1978) reported that burning an ungrazed big sacaton community in the summer and winter in southeastern Arizona reduced the height and cover of big sacaton and stimulated the growth of other grasses and forbs. They found summer fires created more bare ground and encouraged a greater number and variety of annuals than did the winter fire.

Previous studies in Texas have shown forage quality of big sacaton to decrease with increasing plant maturity (Haferkampunpublished data). Quality, however, appeared to be maintained at a higher level with frequent defoliations. Specific responses to defoliation appear to vary by plant species due to intensity, frequency, and season of defoliation as associated with climate, soil fertility, and light. Many researchers have reported dry matter production of grasses to be affected by both frequency and height of defoliation (Holscher 1945; Jameson and Huss 1959; Peterson 1962; Auda et al. 1966; Burton et al. 1969). Total dry matter production can be reduced by close or frequent clipping, but digestible dry matter may be increased by an increased frequency of clipping (Burton et al. 1963). Increases in forage quality appear to result from maintaining plants and plant parts in a younger stage of development.

This study was designed to investigate the impact of defoliation on forage quality and quantity and stand vigor of established big sacaton, selection "PMT-820", growing on the South Texas Plains.

\section{Materials and Methods}

\section{Site Description}

Big sacaton "PMT-820" was drilled in 1968 on $197 \mathrm{~cm}$ centers on an Orelia clay loam (Typic Ochraqualfs, Fine-loamy, Mixed, Hyperthermic) soil in McMullen County, Texas. Average annual precipitation for the area is 58 to $61 \mathrm{~cm}$ with greatest amounts 
Table 1. Schedule of defoliation treatments applied in 1977 and 1978 to a big sacaton located in the South Texas Plains near Whitsett.

\begin{tabular}{|c|c|c|c|c|c|c|c|}
\hline \multirow[b]{4}{*}{ Treatments } & \multirow[b]{4}{*}{$\begin{array}{l}1977 \\
1978\end{array}$} & \multicolumn{6}{|c|}{ Sample-seasons and dates } \\
\hline & & \multicolumn{2}{|c|}{ Spring } & \multicolumn{3}{|c|}{ Summer } & \multirow{3}{*}{ 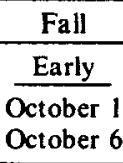 } \\
\hline & & Mid & Late & Early & Mid & Late & \\
\hline & & $\begin{array}{l}\text { May } 11 \\
\text { April } 26\end{array}$ & $\begin{array}{c}\text { June } 8 \\
\text { May } 26\end{array}$ & $\begin{array}{c}\text { July } 7 \\
\text { June } 22\end{array}$ & $\begin{array}{l}\text { August } 3 \\
\text { July } 20\end{array}$ & $\begin{array}{c}\text { September } 3 \\
\text { August } 23\end{array}$ & \\
\hline Nonshredded & & -1 & - & - & - & - & - \\
\hline Monthly (spring/fall) & & $\mathrm{x}^{2}$ & $\mathbf{x}$ & $\mathbf{x}$ & $\mathbf{x}$ & $\mathbf{x}$ & $\mathbf{x}$ \\
\hline Spring/mid-summer & & $\mathbf{x}$ & $\mathbf{x}$ & $\mathbf{x}$ & - & $\mathbf{x}$ & \\
\hline Spring/early summer & & $\mathrm{x}$ & $\mathbf{x}$ & $\mathbf{x}$ & - & - & - \\
\hline Spring & & $\mathbf{x}$ & $\mathbf{x}$ & - & - & - & - \\
\hline Spring-late summer/fall & & $\mathrm{x}$ & $\mathbf{x}$ & - & - & $\mathbf{x}$ & $\mathrm{x}$ \\
\hline Mid-summer/fall & & - & - & & $\mathbf{x}$ & $\mathbf{x}$ & $\mathbf{x}$ \\
\hline
\end{tabular}

'Standing crops were not estimated and plants were not shredded on these dates.

${ }^{2}$ Standing crops were estimated and plants were shredded on these dates.

occurring during May, June, and September. Summers are generally hot and dry, and growing seasons are over 300 days in length. Rainfall has been above average every year since the planting was initiated, and the plants have formed essentially solid stands.

\section{Defoliation Treatments}

Beginning in May 1977, the established stand of big sacaton was subjected to seven defoliation treatments (Table 1). Treatment plots $(3.7$ by $9.2 \mathrm{~m}$ ) were arranged in a randomized complete block design with four replications. The area was fenced to preclude grazing by domestic livestock. Prior to fencing, the area had been grazed by cattle and forage harvested to a $15-\mathrm{cm}$ stubble height was approximately $1,783 \mathrm{~kg} / \mathrm{ha}$.

Plots were shredded to approximately a $15-\mathrm{cm}$ stubble height in 1977 , and all plots were shredded to a $7.5-\mathrm{cm}$ stubble height in February 1978 to remove the remaining standing dead material. With one exception, plots were shredded to the $7.5-\mathrm{cm}$ stubble height during 1978 and again during April 1979. During April 1978 the treated plots were mistakenly shredded to a $15-\mathrm{cm}$ stubble height. At each date, all shredded material was raked off the plots.

\section{Forage Harvested}

Samples used for estimation of the amount of forage harvested were collected before each plot was shredded. In 1977 forage samples were clipped to a $15-\mathrm{cm}$ stubble height in three $1 \times 0.5-\mathrm{m}$ subplots located in each plot. If a plot was not scheduled for shredding, forage harvested was not estimated. The 1977 shredding and harvest dates were May 11, June 8, July 7, August 3, September 3, and October 1 .

In 1978 the method for estimating the amount of forage harvested was modified. Ten randomly located plants per plot were clipped to a 75-cm stubble height, and forage harvests were derived by multiplying the average weight per plant by the average number of plants per plot. The average number of plants per plot was determined in June 1978 by counting the number of plants in each of five systematically placed $1 \times 0.5 \mathrm{~m}$ subplots per main plot. The 1978 shredding and harvest dates were March 30, April 26, May 26, June 22, July 20, August 23, and October 6. Forage harvests were estimated on all plots in October and December 1977, and October 1978 to provide estimates of standing forage on undisturbed plots.

Average maximum foliage heights were measured with leaves extended on plots designated for shredding in 1977, and on all plots after April 1978. Measurements were taken at each clipping site or at five to ten random locations in the plots not scheduled for shredding. The plants heights provided an additional measure of plant response to defoliation.

Average maximum foliage heights were measured and all plots were shredded to a 7.5-cm stubble height on April 6, 1979. Plants were allowed to regrow until June 13,1979, at which time plant heights were measured and standing forage was estimated to provide an index of plant vigor for comparing plant response to 2 consecutive years of defoliation.

\section{Forage Quality}

Forage samples for quality determinations were collected by clipping forage to the $15-\mathrm{cm}$ and $7.5-\mathrm{cm}$ stubble heights in the 1977 and 1978 sampling periods, respectively. Samples were collected on each shredding date and in January, February, and December 1978, and in February 1979. Approximately five samples were collected randomly across the plots scheduled for shredding, or from 1.2-m wide buffer zones on plots not scheduled for shredding. Workers were cautious to not resample previously clipped plants on the plots not shredded the previous month. Following harvesting, samples were sealed in plastic sacks, frozen on dry ice, transported to the laboratory, and stored at below $0^{\circ} \mathrm{C}$. Prior to analysis, samples were placed in paper sacks, oven dried in a forced draft oven at $60^{\circ} \mathrm{C}$ for 48 hours, and then ground to pass a $1-\mathrm{mm}$ screen.

Samples from two replications of each shredding treatment were analyzed for dry matter, organic matter, in vitro digestible organic matter (IVDOM), and total nitrogen content. Dry matter was determined by oven-drying at $105^{\circ} \mathrm{C}$ for at least 12 hours. Ovendried samples were then placed in a muffle furnace at $550^{\circ} \mathrm{C}$ for 3 hours for organic matter determinations. All chemical constituents analyzed in the samples were expressed on an oven-dry, organic matter basis.

The Kjeldahl procedure (A.O.A.C. 1970) was used in determination of nitrogen content of the forage samples. Percent nitrogen was then multiplied by 6.25 and expressed as percent crude protein.

Digestible organic matter was determined employing a 48-hour fermentation of samples with rumen liquor (Tilly and Terry 1963) followed by neutral detergent fiber extraction (Van Soest and Wine 1967). Data were presented as percent IVDOM corrected by a standard forage of known in vivo digestibility.

Table 2. Rainfall (cm) for January 1976 through June 1979 for the big sacaton site located on the South Texas Plains near Whitsett, Texas.

\begin{tabular}{lrrrr}
\hline \hline & \multicolumn{4}{c}{ Years } \\
\cline { 2 - 5 } Month & 1976 & 1977 & 1978 & 1979 \\
\hline January & 0.9 & 12.1 & 1.9 & 8.1 \\
February & 0.0 & 5.8 & 3.2 & 3.7 \\
March & 2.2 & 2.2 & 0.0 & 2.5 \\
April & 13.2 & 21.2 & 1.5 & 11.8 \\
May & 20.7 & 4.4 & 10.0 & 5.2 \\
June & 1.1 & 11.4 & 14.1 & 16.5 \\
July & 17.6 & 1.1 & 10.7 & \\
August & 4.2 & 0.2 & 12.4 & \\
September & 9.0 & 10.5 & 8.2 & \\
October & 27.6 & 19.6 & 1.6 & \\
November & 8.8 & 7.2 & 8.6 & \\
December & 6.6 & 0.2 & 7.7 & \\
Total & 11.9 & 95.9 & 79.9 & \\
\hline
\end{tabular}


Statistical analysis of the data consisted of an analysis of variance for IVDOM and crude protein within months, within years, and pooled over years. The interaction of treatment and year was tested and Duncan's multiple range test was performed as indicated to test differences between treatments.

\section{Results}

Approximately 96 and $80 \mathrm{~cm}$ of rainfall fell on the study site during 1977 and 1978, respectively (Table 2). An additional $48 \mathrm{~cm}$ fell prior to mid-June 1979. The rainfall pattern was characterized by relatively dry periods during the early spring, summer, and winter of 1977 and the winter and spring of 1978. In addition, only $0.25 \mathrm{~cm}$ of rainfall occurred from June 8 to July 22, 1978.

\section{Forage Harvests and Plant Heights in 1977 and 1978}

Approximately $1,783 \mathrm{~kg} / \mathrm{ha}$ of big sacaton were removed when plots were defoliated in mid spring of 1977 (Table 3). In late spring an average of $1,192 \mathrm{~kg} / \mathrm{ha}$ was harvested from the defoliated plots. The rate of regrowth progressively declined with defoliations in early and midsummer. Defoliation of plots shredded the previous month removed an average of $830 \mathrm{~kg} / \mathrm{ha}$ big sacaton forage in July, $527 \mathrm{~kg} / \mathrm{ha}$ in August, and $117 \mathrm{~kg} / \mathrm{ha}$ in September. The initial harvest of the midsummer/fall plots in 1977 removed $3,386 \mathrm{~kg} / \mathrm{ha}$. However, regrowth was slow, and the depressed growth was attributed to the lack of rainfall and soil moisture, when only $1.3 \mathrm{~cm}$ of rainfall occurred in July and August.

During the May to October 1977 harvest period, over 4,000 $\mathrm{kg} / \mathrm{ha}$ of forage were removed by the monthly, spring/midsummer, spring/late-summer/fall and midsummer/fall treatments. Plots in each of these treatments were defoliated three times or more during the season and three of the treatments included fall harvests. Approximately 2,900 and $3,800 \mathrm{~kg} / \mathrm{ha}$ of forage were harvested from the spring and spring/midsummer plots, respectively. By early winter the nonshredded and spring treatments supported the most forage of 4,610 and $1,406 \mathrm{~kg} / \mathrm{ha}$, respectively. Standing forage on the other treatments ranged from 551 to 743 $\mathrm{kg} / \mathrm{ha}$. Accumulated forage harvests including the residue remaining on the plots not shredded in the fall ranged from 5,694 to 4,295 $\mathrm{kg} / \mathrm{ha}$ for 1977 treatments (Table 3).

Heights of early spring defoliated plants ranged from 64 to $75 \mathrm{~cm}$ in late spring. Maximum heights of 106 and $115 \mathrm{~cm}$ were recorded in midsummer for plants defoliated in late summer/fall and in early fall for plants in the nonshredded plots, respectively. Min- imum heights of 14 to $25 \mathrm{~cm}$ were recorded for the spring/midsummer treatment in August and the midsummer/fall plots in September, respectively.

In mid-spring 1978, approximately $500 \mathrm{~kg} / \mathrm{ha}$ of forage were removed by all except the spring treatment (Table 4). Replication one of this treatment was consistently more productive than other plots of this block. The cause of the greater productivity was not determined. The relatively small amounts of forage, $640 \mathrm{~kg} / \mathrm{ha}$ and $410 \mathrm{~kg} / \mathrm{ha}$ harvested in mid and late spring of 1978 , respectively, resulted from a previous dry winter and a total rainfall of $4.7 \mathrm{~cm}$ during February, March, and April (Table 2). By early summer, forage harvested from the monthly, spring/midsummer and spring/early-summer plots averaged $1,302 \mathrm{~kg} / \mathrm{ha}$. Growth was undoubtedly enhanced by the increase in soil moisture from 24.1 $\mathrm{cm}$ rainfall received in May and June. Forage harvested from the plots treated monthly was less than $300 \mathrm{~kg} / \mathrm{ha}$ and $600 \mathrm{~kg} / \mathrm{ha}$ in midsummer and late summer, respectively. The midsummer harvest of previously defoliated plots was the only one to yield less than $300 \mathrm{~kg} / \mathrm{ha}$ in 1978. Lack of rainfall had reduced plant regrowth when only $0.25 \mathrm{~cm}$ rain fell from June 8 to July 22,1978 . The initial harvest of the midsummer/fall plots removed $3,054 \mathrm{~kg} / \mathrm{ha}$. The regrowth after the initial harvest was greater than in 1977 and was in part due to increased rainfall and improved growing conditions.

During the 1978 treatment period, approximately $4,000 \mathrm{~kg} / \mathrm{ha}$ were harvested from the monthly and spring/late-summer/fall defoliated plots and $5,200 \mathrm{~kg} / \mathrm{ha}$ were harvested from the midsummer/fall plots. These plots were defoliated three or more times and all were defoliated in the fall. Approximately $2,000 \mathrm{~kg} / \mathrm{ha}$ were removed from the other three treatments by harvesting during spring to midsummer. The nonshredded and spring defoliated plots supported 6,204 and $4,831 \mathrm{~kg} / \mathrm{ha}$ of big sacaton forage in the fall and the plots defoliated in spring to early or midsummer supported approximately $1,500 \mathrm{~kg} / \mathrm{ha}$.

Plant heights in (March) 1978 indicated nonshredded plants (39 $\mathrm{cm}$ ) were significantly taller than plants in the other treatments. Plants defoliated only in the spring averaged $35 \mathrm{~cm}$, and those of other treatments ranged in height from 29 to $30 \mathrm{~cm}$. These data suggest that at least a slight decrease in plant height occurred with any defoliation during the 1977 growing season.

Big sacaton plants averaged 30 to $40 \mathrm{~cm}$ in height by April 1978 regardless of defoliation treatment. Through early summer the plants in the nonshredded and midsummer/fall plots were not defoliated and were the tallest, averaging 99 and $83 \mathrm{~cm}$, respec-

Table 3. Forage harvested (kg/ha) from big sacaton stands defoliated to a $15 \mathrm{~cm}$ stubble height on the South Texas Plains near Whitsett, from May 11 to December 6, 1977.

\begin{tabular}{|c|c|c|c|c|c|c|c|c|}
\hline \multirow[b]{3}{*}{ Treatments } & \multicolumn{7}{|c|}{ Sample seasons and dates } & \multirow{3}{*}{$\begin{array}{l}\text { Accumulated } \\
\text { forage } \\
\text { harvested and } \\
\text { residue on } \\
\text { plots }\end{array}$} \\
\hline & \multicolumn{2}{|c|}{ Spring } & \multicolumn{3}{|c|}{ Summer } & \multirow{2}{*}{$\frac{\text { Fall }}{\text { Early }}$} & \multirow{2}{*}{$\frac{\text { Winter }}{\text { Early }} \frac{\text { Dec. } 6}{\text { Den }}$} & \\
\hline & $\frac{\text { Mid }}{\text { May } 11}$ & $\frac{\text { Late }}{\text { June } 8}$ & $\frac{\text { Early }}{\text { July } 7}$ & $\frac{\text { Mid }}{\text { Aug. } 3}$ & $\frac{\text { Late }}{\text { Sept. } 3}$ & & & \\
\hline Nonshredded & - & - & - & - & - & $\begin{array}{r}2,992^{2} \\
(560)\end{array}$ & $\begin{array}{r}4,610 \\
(1,155)\end{array}$ & 4,610 \\
\hline Monthly (spring/fall) & 1,783 & $\begin{array}{l}1,363 \\
(576)^{1}\end{array}$ & $\begin{array}{c}805 \\
(305)\end{array}$ & $\begin{array}{c}579 \\
(928)\end{array}$ & $\begin{array}{c}117 \\
(134)\end{array}$ & $\begin{array}{c}345 \\
(271)\end{array}$ & $\begin{array}{c}702 \\
(206)\end{array}$ & 5,694 \\
\hline Spring/mid-summer & 1,783 & $\begin{array}{l}1,280 \\
(528)\end{array}$ & $\begin{array}{c}756 \\
(311)\end{array}$ & $\begin{array}{c}475 \\
(257)\end{array}$ & - & $\begin{array}{r}459^{2} \\
(192)\end{array}$ & $\begin{array}{c}725 \\
(187)\end{array}$ & 5,019 \\
\hline Spring/early summer & 1,783 & $\begin{array}{c}1,093 \\
(443)\end{array}$ & $\begin{array}{c}930 \\
(273)\end{array}$ & 一 & - & $\begin{array}{r}494^{2} \\
(475)\end{array}$ & $\begin{array}{c}743 \\
(354)\end{array}$ & 4,549 \\
\hline Spring & 1,783 & $\begin{array}{r}1,106 \\
(886)\end{array}$ & - & - & - & $\begin{array}{l}1,691^{2} \\
(1,112)\end{array}$ & $\begin{array}{c}1,406 \\
(968)\end{array}$ & 4,295 \\
\hline Spring-late summer/fall & 1,783 & $\begin{array}{l}1,118 \\
(304)\end{array}$ & - & - & $\begin{array}{c}1,157 \\
(215)\end{array}$ & $\begin{array}{c}588 \\
(213)\end{array}$ & $\begin{array}{l}551 \\
(216)\end{array}$ & 5,197 \\
\hline Mid-summer/fall & - & - & - & $\begin{array}{c}3,386 \\
(2,709)\end{array}$ & $\begin{array}{c}13 \\
(18)\end{array}$ & $\begin{array}{r}660 \\
(420)\end{array}$ & $\begin{array}{c}715 \\
(172)\end{array}$ & 4,774 \\
\hline
\end{tabular}

IStandard Deviation

2These values were not included in the accumulated yields, because the plots were not defoliated in October. 
Table 4. Forage harvested (kg/ha) from big sacaton stands defoliated to a $7.5 \mathrm{~cm}$ stubble height on the South Texas Plains near Whitsett from April 26 to October 6, 1978.

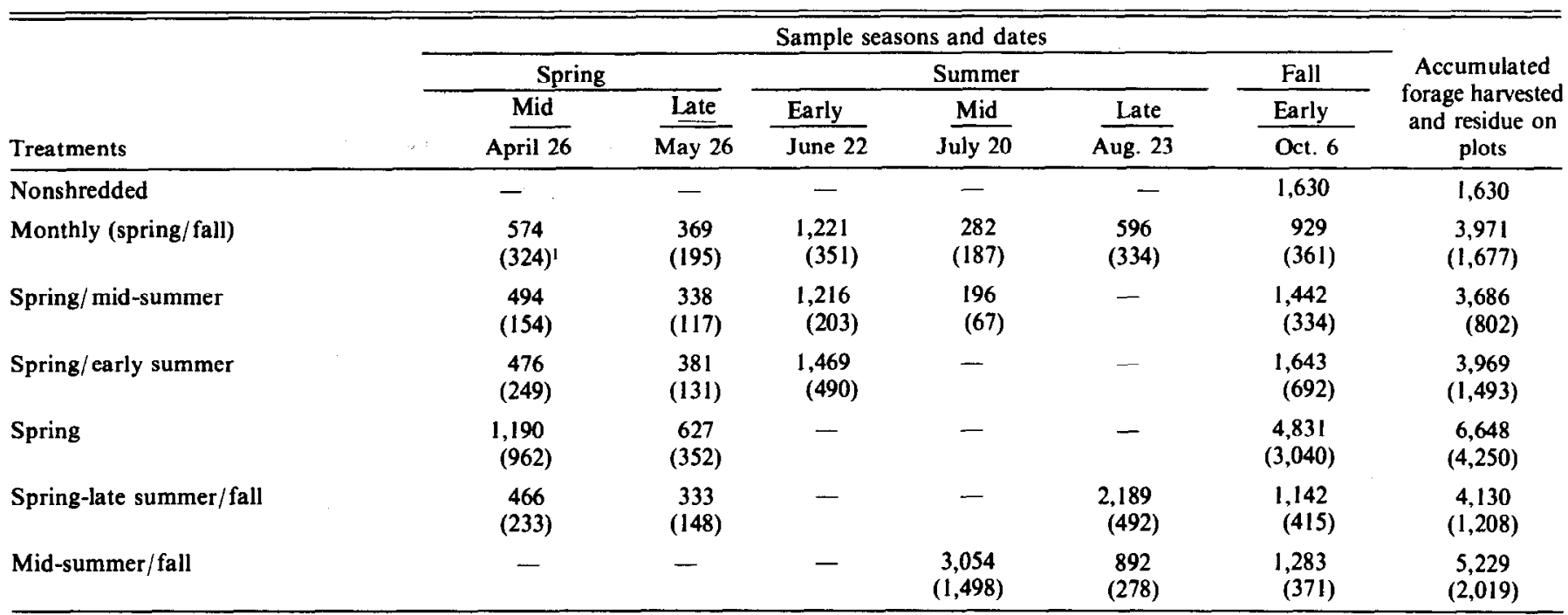

'Standard Deviation

tively. Plants in the spring and spring/late-summer/fall treatments, averaged 66 and $69 \mathrm{~cm}$, respectively, in early summer, and they were significantly taller than the 50 to $52 \mathrm{~cm}$ average height for plants defoliated monthly, or in spring/midsummer, and spring /early summer. The difference in June heights may have reflected the previous year's treatment. Minimum plant heights of 16 to 19 $\mathrm{cm}$ were recorded in midsummer for the monthly, spring, midsummer, and spring/early-summer treatments.

\section{Forage Quality in 1977 and 1978}

Forage quality of big sacaton forage was significantly affected by defoliation and weather conditions in 1977 and 1978. Crude protein content was significantly different among treatments in 1978 in all except the late-summer sampling period. Similarly the IVDOM content was significantly different among treatments except for the mid- and late-summer harvests. These summer harvests followed very dry and hot periods and the weather conditions appeared to enhance maturation of forage as well as reduce regrowth on recently defoliated plants. The lack of regrowth prevented collection of a forage quality sample from replication two of the midsummer/fall treatment. Replications two and four were drier than one and three.

During the 1978 harvest crude protein and IVDOM contents differed significantly among treatments from midsummer 1978 to late winter 1979. In contrast to 1977 , forage quality was not significantly different between treatments during spring and early summer 1978. Rainfall was greater during May through Sep- tember of 1978 compared to 1977 , although a dry period occurred during June and July which prevented regrowth in block two of the monthly and spring/ early-summer treatments. The probable cause of lack of significant treatment effect in spring and early summer 1978 , however, was a reduction in standing dead forage in samples collected from the nonshredded and midsummer/fall plots. In 1977 treatments were begun with $1,783 \mathrm{~kg} /$ ha standing forage above the $15 \mathrm{~cm}$ stubble height which contained some standing dead forage, but all plots were defoliated to $7.5-\mathrm{cm}$ stubble height in February 1978 to remove the influence of standing dead.

Big sacaton forage contained 0.6 to $5.8 \%$ more crude protein during spring through late summer harvest in 1978 than in 1977. IVDOM content was 0.8 to $8.3 \%$ greater during the spring through early-fall harvest in 1978 than in 1977 . The 1977 crude protein and IVDOM contents, however, averaged 1.7 to $1.1 \%$ and 7.5 to $8.2 \%$ grcater, respectively, during the early and late winter collections. The improved quality during the spring, summer, and early fall of 1978 was due to decreased standing dead in some forage samples and the better growing conditions provided by the increased rainfall in 1978. Fall regrowth in response to $30.1 \mathrm{~cm}$ rainfall in September and October improved forage quality in the winter of $1977-78$, and early hard freeze caused a decline in forage quality in the winter of 1978-79.

The 1977 and 1978 crude protein and IVDOM contents were pooled for ease of presentation of defoliation effects. Significant treatment-by-year interactions were found for crude protein content for all but the late-summer collection and for IVDOM content

Table 5. Average percentage crude protein contained in big sacaton forage harvested from the South Texas Plains near Whitsett during May 1977 to February 1979.

\begin{tabular}{|c|c|c|c|c|c|c|c|c|c|c|c|}
\hline \multirow[b]{4}{*}{ Treatments } & \multirow[b]{4}{*}{$\begin{array}{l}1977-78 \\
1978-79\end{array}$} & \multicolumn{10}{|c|}{ Sample seasons and dates } \\
\hline & & \multicolumn{2}{|c|}{ Spring } & \multicolumn{3}{|c|}{ Summer } & \multirow{2}{*}{$\frac{\text { Fall }}{\text { Eariy }}$} & \multicolumn{3}{|c|}{ Winter } & \multirow[b]{3}{*}{ Average } \\
\hline & & Mid & Late & Early & Mid & Late & & Early & Mid & Late & \\
\hline & & $\begin{array}{c}- \\
\text { April } 26\end{array}$ & $\begin{array}{l}\text { June } 8 \\
\text { May } 26\end{array}$ & $\begin{array}{l}\text { July } 7 \\
\text { June } 22\end{array}$ & $\begin{array}{l}\text { Aug. } 3 \\
\text { July } 20\end{array}$ & $\begin{array}{l}\text { Sept. } 3 \\
\text { Aug. } 23\end{array}$ & $\begin{array}{l}\text { Oct. } 1 \\
\text { Oct. } 6\end{array}$ & $\begin{array}{l}\text { Dec. } 7 \\
\text { Dec. } 26\end{array}$ & $\begin{array}{c}\text { Jan. } 26 \\
-\end{array}$ & $\begin{array}{l}\text { Feb. } 16 \\
\text { Feb. } 9\end{array}$ & \\
\hline Nonshredded & & $10.1 b^{1}$ & $9.5 \mathrm{~d}$ & $7.0 \mathrm{~d}$ & $5.8 \mathrm{c}$ & $5.2 \mathrm{~d}$ & $6.4 \mathrm{e}$ & $5.8 \mathrm{~d}$ & $5.4 \mathrm{e}$ & $5.8 \mathrm{e}$ & $6.8 \mathrm{c}$ \\
\hline Monthly (spring/fall) & & $12.3 \mathrm{a}$ & $11.5 \mathrm{ab}$ & $10.5 a$ & $10.3 a$ & $11.9 \mathrm{a}$ & $12.1 \mathrm{a}$ & $12.4 a$ & $10.9 \mathrm{a}$ & $10.8 \mathrm{a}$ & $11.4 \mathrm{a}$ \\
\hline Spring/mid-summer & & $12.0 \mathrm{ab}$ & $10.4 \mathrm{bcd}$ & $8.9 c$ & $9.7 \mathbf{a}$ & $10.0 \mathrm{~b}$ & $10.9 \mathrm{bc}$ & $9.6 \mathrm{bc}$ & 9.1 bcd & $8.6 c$ & $9.8 \mathrm{~b}$ \\
\hline Spring/early summer & & $12.3 \mathrm{a}$ & $11.2 \mathrm{bc}$ & $9.4 \mathrm{abc}$ & $10.2 \mathrm{a}$ & $10.3 b$ & $10.6 \mathrm{c}$ & $8.5 \mathrm{c}$ & $8.9 \mathrm{~cd}$ & $7.6 \mathrm{~d}$ & $9.9 \mathrm{~b}$ \\
\hline Spring & & $12.9 \mathrm{a}$ & $12.4 a$ & $10.1 \mathrm{ab}$ & $7.5 \mathrm{~b}$ & $7.3 c$ & $8.6 \mathrm{~d}$ & $10.0 \mathrm{bc}$ & $8.6 d$ & $7.7 \mathrm{~d}$ & $9.4 \mathrm{~b}$ \\
\hline Spring/late-summer/fall & & $12.1 \mathrm{a}$ & $10.3 \mathrm{~cd}$ & $9.3 \mathrm{bc}$ & $7.2 \mathrm{bc}$ & $6.6 \mathrm{~cd}$ & $10.9 \mathrm{bc}$ & $10.9 \mathrm{ab}$ & $10.0 \mathrm{abc}$ & $10.2 \mathrm{ab}$ & $9.7 b$ \\
\hline Mid-summer/fall & & $12.8 \mathrm{a}$ & $10.7 \mathrm{bc}$ & $7.2 \mathrm{~d}$ & $6.4 \mathrm{bc}$ & $10.9 a b$ & $11.5 a b$ & $11.3 \mathrm{ab}$ & $10.1 \mathrm{ab}$ & $9.8 \mathrm{~b}$ & $10.0 \mathrm{~b}$ \\
\hline
\end{tabular}

'Means within a column followed by the same letter are not significantly different at the $95 \%$ level according to Duncan's new multiple range test. 
Table 6. A verage percentage IVDOM contained in big sacaton forage harvested from the South Texas Plains near Whitsett during May 1977 to February 1979.

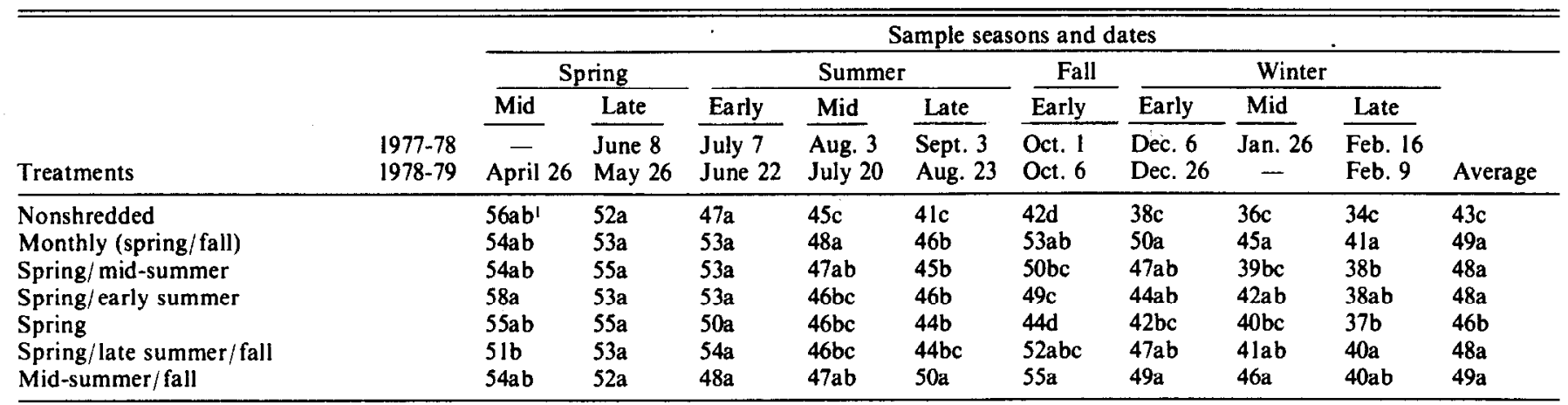

'Means within a column followed by the same letter are not significantly different at the $95 \%$ level according to Duncan's new multiple range test.

for the mid and late-summer and late-winter collections. The significant interactions were due to several factors: the standing dead forage contained in nonshredded samples in 1977 , the difference in rainfall for the 2 years, and the missing data due to lack of plant regrowth during dry periods.

Crude protein contents were significantly increased by defoliation in 1977 and 1978 harvests (Table 5). Averaged across all dates the plants defoliated monthly contained the most crude protein and the nonshredded plants contained the least amount. Plants of all treatments contained over $9 \%$ crude protein in spring. By early summer, treatment effects became obvious and plants defoliated during the spring contained significantly more crude protein than plants which had not been defoliated. Midsummer quality was improved by the carly summer shredding and the monthly, spring/ midsummer, and spring/early summer plants contained significantly greater crude protein content than other plants. By late summer all plots except the nonshredded had been defoliated at least once, and forage from the monthly, spring/midsummer, spring/early summer, and midsummer/fall treatments contained the most crude protein. Each of these plots had been defoliated during the previous 2 months. Plants defoliated in early summer or later contained over $10 \%$ crude protein in the fall, significantly more crude protein than in spring defoliated plants. Plants defoliated at any time during the harvest period contained significantly more crude protein than the nonshredded plants during the fall and winter. By late winter the plants defoliated in the fall contained significantly more crude protein than plants of all other treatments. Plants defoliated the last time in midsummer contained more crude protein than plants shredded last in spring or early summer.

IVDOM contents did not appear to change as rapidly with defoliation as the crude protein contents. Averaged across all dates the monthly and midsummer/fall plants contained the higher percentages of IVDOM and the nonshredded plants contained the least (Table 6). The IVDOM contents were similar among treat- ments during spring and early summer. Digestibilities by. early summer, however, decreased to below $50 \%$ in the plants that had not been previously shredded. By midsummer IVDOM contents of all treatments had decreased to below $50 \%$, and differences due to defoliation were not obvious. The midsummer/fall plants contained approximately 50\% IVDOM in late summer. The digestibility of these plants was significantly greater than for other plants shredded a month earlier, monthly and spring/midsummer treatments, but there was not an obvious explanation for this difference. Plants shredded in late summer were the only plants that contained over $50 \%$ IVDOM in the fall. All plants shredded in early summer or later, however, contained significantly more IVDOM in fall than nonshredded or spring treated plants. A similar trend in IVDOM occurred in winter collections. The plants shredded during the growing season consistently contained more IVDOM than the nonshredded piants, although consistent differences were not obvious among other treatments.

\section{Response}

Standing forage and plant heights were again measured in spring and early summer 1979 to evaluate the effects of 2 consecutive years of shredding on big sacaton stands. Plant heights were measured and all plots were shred to a 7.5-cm stubble height on April 6, 1979. Plants were then allowed to regrow and stands were sampled for plant heights and standing forage on June 13, 1979.

By April 6, 1979, plants of the nonshredded treatment were the tallest (Table 7). Plants defoliated in spring through midsummer were intermediate in height and any plants that had been defoliated in the fall were the shortest. A similar trend was found for heights of regrowth measured in late spring 1979. Standing forage in late spring was also greatest for plants of the nonshredded treatment. The spring and spring/early summer defoliations appeared to have minimal effects on standing forage. Any treatment with a fall defoliation appeared to be the most detrimental to the vigor of big sacaton stands. With the exception of the spring-late summer/fall and midsummer/fall treatments there appeared to be a trend for a

Table 7. Plant heights (cm), plant weights (g), and standing forage (kg/ha) at a clipping height of $7.5 \mathrm{~cm}$ on June 13, 1979, for big sacaton stands defoliated at different frequencies.

\begin{tabular}{|c|c|c|c|c|}
\hline \multirow[b]{3}{*}{ Treatments } & \multicolumn{2}{|c|}{ Height } & & \\
\hline & \multirow{2}{*}{$\frac{\text { Mid spring }}{\text { April 6, } 1979}$} & \multirow{2}{*}{$\begin{array}{l}\text { Late spring } \\
\text { June } 13,1979\end{array}$} & \multicolumn{2}{|c|}{ Standing forage-June 1979} \\
\hline & & & Per plant (g) & Total (kg/ha) \\
\hline $\begin{array}{l}\text { Nonshredded } \\
\text { Monthly (spring/fall) } \\
\text { Spring/mid-summer } \\
\text { Spring/early summer } \\
\text { Spring } \\
\text { Spring/late summer/fall } \\
\text { Mid-summer/fall }\end{array}$ & $\begin{array}{l}84 \mathrm{a}^{\prime} \\
48 \mathrm{e} \\
56 \mathrm{~d} \\
70 \mathrm{~b} \\
69 \mathrm{c} \\
46 \mathrm{e} \\
36 \mathrm{f}\end{array}$ & $\begin{array}{l}74 a \\
45 c \\
61 b \\
61 b \\
72 a b \\
46 c \\
49 c\end{array}$ & $\begin{array}{l}111 \mathrm{a} \\
30 \mathrm{c} \\
40 \mathrm{bc} \\
52 \mathrm{bc} \\
68 \mathrm{~b} \\
23 \mathrm{c} \\
33 \mathrm{c}\end{array}$ & $\begin{array}{r}3,285 \mathrm{a} \\
1,188 \mathrm{de} \\
1,852 \mathrm{~cd} \\
2,265 \mathrm{bc} \\
2,769 \mathrm{ab} \\
876 \mathrm{de} \\
1,090 \mathrm{de}\end{array}$ \\
\hline
\end{tabular}

'Means in the column with the same letter are not significantly different at the $95 \%$ level according to Duncan's new multiple range test. 
Table 8. The total amount of big sacaton forage (kg/ha) harvested during the sampling periods, May to December 1977 and April to October 1978, and the total amount of forage (kg/ha) left as residual during the two winters.

\begin{tabular}{lccc}
\hline \hline Treatments & Total & Harvested & Residual \\
\hline Nonshredded & 10,814 & 0 & 10,814 \\
Monthly & 9,665 & 8,963 & 702 \\
Spring/mid-summer & 8,705 & 6,538 & 2,167 \\
Spring/early summer & 8,518 & 6,132 & 2,386 \\
Spring & 10,943 & 4,706 & 6,237 \\
Spring-late summer/fall & 9,327 & 8,776 & 551 \\
Mid-summer/fall & 10,003 & 9,288 & 715 \\
\hline
\end{tabular}

decreased plant weight and yield with an increase in the number of times plants were defoliated. The exposure of fall defoliated plants to low winter temperatures may have been a factor in reducing plant vigor during the winter of 1978 . Several researchers reported die-out of some grass species following the cold winter. Greater death losses were observed on areas defoliated late in 1978, thus resulting in smaller standing crops during the winter.

\section{Management Implications}

During the 1977 and 1978 growing seasons, the largest amounts of forage were harvested from plots that were defoliated three or more times and were defoliated in the fall (Table 8). The least amounts of forage were harvested from plots defoliated in spring, spring/early summer and spring/midsummer. In the fall and winter the nonshredded and spring defoliated plots supported relatively large amounts of forage and the spring/early summer and spring/midsummer plots supported intermediate amounts of forage that were available as roughage for grazing livestock.

Stand vigor was maintained best by brief periods of use in the spring or spring/early summer, followed by utilization of old forage in late winter. Harvesting to a stubble height of less than 7.5 $\mathrm{cm}$ may have been too severe and a taller stubble height needs to be maintained during the winter to provide some protection against low temperature winter die-off.

Maintenance of high quality big sacaton forage was related to plant maturity and rainfall. A higher level of forage quality was maintained by removing old growth before spring. With subsequent defoliations and adequate soil moisture plants regrew, producing new herbage which was higher in quality than the more mature forage remaining from earlier defoliations.

Based on these data the spring/early summer system provided large amounts of high quality forage and maintained stand vigor.
This system defoliated plants when soil moisture was usually adequate for plant regrowth, provided nutritious forage during the growing season, and provided adequate standing crop for fall and winter grazing and protection against damage due to low temperature.

\section{Literature Cited}

Ass. Ofinc. Agr. Chem. 1979. Official Methods of Analysis. (11th ed.) Ass. of Offic. Agr. Chem. Washington, D.C. 10015 p.

Auda, H., R.E. Blaser, and R.H. Brown. 1966. Tillering and carbohydrate contents of orchardgrass as influenced by environmental factors. Crop Sci. 6:139-143.

Bock, C.E., and J.H. Bock. 1978. Response of birds, small mammals, and vegetation to burning sacaton grasslands in southeastern Arizona. J. Range Manage. 31:296-300.

Burton, G.W., J.E. Jackson, and R.H. Hart. 1963. Effect of cutting frequency and nitrogen on yield, in vitro digestibility, and protein, fiber, and carotene content of coastal bermudagrass. Agron. J. 55:500-502.

Burton, G.W., W.S. Wilkinson, and R.L. Carter. 1969. The effect of nitrogen, phosphorus, and potassium levels, and clipping frequency on the forage yield and protein, carotene, and xanthopyll contents of coastal bermudagrass. Agron. J. 61:60-63.

Griffiths, D., G.L. Bidwell, and C.E. Goodrich. 1915. Native pasture grasses of the United States. U.S. Dep. Agr. Bull. 201. 52 p.

Holscher, C.E. 1945. The effects of clipping bluestem wheatgrass and bluegrama at different heights and frequency. Ecology 26:148-156.

Humphrey, R.R. 1960. Arizona range grasses. Arizona Agr. Exp. Sta. Bull. 298. $104 \mathrm{p}$.

Jameson, D.A., and D.L. Huss. 1959. The effect of clipping leaves and stems on number of tillers, herbage weights, root weights, and food reserves in little bluestem. J. Range Manage. 12:122-126.

Peterson, R.A. 1962. Factors affecting resistance to heavy grazing in needle-and-thread grass. J. Range Manage. 15:183-189.

Soil Conservation Service. 1979. Planting guide. In: U.S. Dep. Agr. Soil Conservation Service National Plant Material Handbook.

Tilley, J.M.A., and R.A. Terry. 1963. A two-stage technique for the in vitro digestion of forage crops. J. Brit. Grassl. Soc. 18:104

United States Forest Service. 1937. Range plant handbook. U.S. Dep. Agr. PB 168589.

Van Soest, P.J., and R.H. Wine. 1967. Use of detergents in the analysis of fibrous feeds: IV. The Determination of plant cell-wall constitucnts. J. Ass. Offic. Agr. Chem. 50:50-55.

Wooten, E.O., and P.C. Standley. 1912. The grasses and grass-like plants of New Mexico. N. Mex. Agr. Exp. Sta. Bull. 81. 176 p.

Youngner, V.B. 1972. Physiology of defoliation and regrowth, p. 292-303. In: Youngner, V.B. and C.M. McKell (eds.). The Biology and Utilization of Grasses. Academic Press, New York. 